\title{
From Homo Sovieticus to Homo Zapiens: Viktor Pelevin's Consumer Dystopia
}

\author{
SOFYA KHAGI
}

B oasting a rich tradition of utopian/dystopian fiction, Russian literature has seen the most recent burgeoning of the genre in the late twentieth and early twenty-first centuries. With the advancement of Gorbachev's reforms in the mid-1980s, Russian writers engaged in an increasingly open attack on the mythology of Socialist utopia. It was during those years that the negative subgenre of dystopia once again came to the forefront of literature. As the collapse of the Soviet empire seemed more and more imminent, a number of parodic treatments of the Socialist experiment appeared, as well as more somber works concerned with the menaces attending the looming breakdown of the Soviet state. ${ }^{1}$ Whether writing in the primarily satiric vein used by Voinovich, Veller, and Aksenov, or in the more wistful spirit exemplified by the Strugatsky brothers in their later oeuvre, the writers of Gorbachev's epoch sought to reinterpret the past and to discern possible venues for the country's future. These attempts continued after the fall of the Soviet Union.

This article examines Viktor Pelevin's Generation " $\Pi$ ", one of the most conspicuous turn-of-the-century Russian novels. It can be productively analyzed as a fin-de-siècle expression of dystopian imagination. ${ }^{2}$ I view Pelevin's work as marking a crucial watershed in the development of the genre in Russia. While dystopias written during perestroika, including Pelevin's Omon Ra and some of his early short stories from the collection Blue Lantern, were mainly preoccupied with the deconstruction of Soviet utopia, and with prognostications of the possible consequences of the country's breakdown, Generation " $\Pi$ " is the first major post-Soviet work to come to grips with the introduction of consumer capitalism and global pop culture. As the euphoria of the early 1990s was dispersed quickly in the face of harsh new economic realities, and as the no less tyrannical demands of the

I am very grateful to Dr. Michael Gorham and my anonymous referees for their insightful comments on the essay.

${ }^{1}$ Two examples of these trends are, respectively, Vladimir Voinovich, Moscow 2042, trans. Richard Lourie (San Diego, 1987); and Alexander Kabakov, No Return, trans. Thomas Whitney (New York, 1990).

${ }^{2}$ Irina Rodnianskaia spots some of the novel's dystopian interests in "Etot mir priduman ne nami," Novyi mir, 1999, no. 8. A more thorough analysis is in order.

The Russian Review 67 (October 2008): 559-79

Copyright 2008 The Russian Review 
market replaced ideological control of the Soviet period, an attitude to the brave new order became more uncomfortable.

Following the termination of the Socialist experiment, militant collectivist dystopia retreated, and the genre began to focus on the "consumer dream" as the remaining utopian venture. Generation " $\Pi$ " sets up the parameters for contemporary Russian techno-consumer dystopia and anticipates Pelevin's later works-DPP $(N N) /$ The Dialectics of the Transitional Period from Nowhere to Nowhere, Werewolf's Sacred Book, and Empire V/Ampir V-as well as a veritable outburst of consumer dystopias produced in Russia during the first decade of the new millennium by Aksenov, Garros, Evdokimov, Minaev, Rybakov, Latynina, and other writers. I argue that Generation " $\Pi$ " both builds upon and subverts traditional dystopian paradigms, offering a multilayered dystopian critique that, despite its dutiful ironies and becoming bashfulness of any claims to authority, reveals a more thorough social skepticism than its more solemn forebears. ${ }^{3}$

Dystopias share several genre markers: the portrayal of an evil social structure; a defamiliarizing and/or fantastic element; entry into an exchange with the heritage of utopian/ dystopian thought; and common themes like mind/body control, technology, the collective versus the individual, reason versus imagination and art, and urbanity versus nature. ${ }^{4}$ At the same time, of the two best-known twentieth-century dystopias, Orwell's 1984 reacted largely to the totalitarianism of the Soviet/Nazi state, while Huxley's Brave New World focused mainly on consumerism, technological development, and "the psychological poverty of groups" of the North American jazz age. ${ }^{5}$ Orwell's autocratic dystopia features extreme governmental tyranny, a penal system that employs physical and psychological torture, ubiquitous police forces, a personality cult, and a meager quality of life. Huxley's novel is a denunciation of "greed and its ennoblement."

Rather than relying on Orwell's archetypal indictment of the militant totalitarian state, Pelevin's work follows Huxley's portrayal of "the world of our Ford." Vavilen Tatarsky, the hero of Generation " $\Pi$ ", comes of age as the Soviet Union disintegrates. As a youngster, he was an aspiring poet and a student of the Moscow Literary Institute. With the collapse of the country, Tatarsky becomes, first, a lowly shop assistant, and, later, an advertising copywriter, whose job is to concoct Russian ads patterned on up-to-date American advertising technologies. As he prospers in the advertising business, there unfolds before the reader a savage spoof of Russia's transformation into a grotesque capitalist realm of drug dealers, nouveau riches, a sinister corporate underworld, and mystifying political plots. Like Huxley's novel, Generation " $\Pi$ " is a scathing satire of cultural degradation and rampant consumerism. Pelevin's post-Soviet Russia is overwhelmed by a sudden onslaught of

\footnotetext{
${ }^{3}$ The esoteric layer of the text does not constitute this essay's primary focus, although I do consider the Babylon dimension of the novel insofar as it enters Pelevin's dystopian critique. Pelevin's use of language and the role of drug culture in his work are beyond the scope of the essay.

${ }^{4}$ For a detailed discussion of dystopian conventions see Krishan Kumar, Utopia and Anti-Utopia in Modern Times (Oxford, 1987); and M. Keith Booker, Dystopian Literature: A Theory and Research Guide (Westport, 1994).

${ }^{5}$ The term "psychological poverty of groups" was offered by Sigmund Freud in Civilization and Its Discontents (New York, 1991), 74. Eugene Zamyatin's We, a key Huxlean and Orwellian predecessor, responded to both totalitarian Soviet tendencies and Western mechanized culture.

${ }^{6} J u l i a n$ Huxley, ed., Aldous Huxley 1894-1963: A Memorial Volume (London, 1965), 72.
} 
Western goods and media. It is a world of endless soap operas and meaningless advertising jingles. Likewise, as in Huxley, it is a surreptitiously totalitarian society in which total control is achieved not by crude force but through saturating the populace with products of mass culture that serve as a subtle tool of social conditioning. The individual disappears in favor of a homogenous, mind-numbed mass. There is no need to torture a Winston Smith into loving Big Brother, for post-Soviet Winston Smiths have neither the time nor the capacity for resistance, absorbed as they are in a relentless pecuniary cycle. No more hate minutes, torture chambers, and suppression of sex. Instead, crass materialism, mind-stultifying popular entertainment, destruction of historical and cultural consciousness through kitsch, and corruption are the pillars of the new society.

In this scheme, television plays a crucial role. The epigraph from Leonard Cohen with its "hopeless little screen" initiates Pelevin's investigation of the impact of advanced media technologies on modern man. ${ }^{7}$ As explained in a mock-scholarly treatise attributed to the spirit of Che Guevara, television transforms the populace into "Homo Zapiens" (from zapping, changing channels to avoid watching advertisements), zombies manipulated by global, profit-driven information space:

The changes in the image produced by various technomodifications can be correlated with a virtual psychological process in which the observer is forced to ... manage his own attention as the makers of the program manage it. This psychological process creates its own virtual subject, which for the duration of the television program exists in the place of the individual ... Assuming the condition of Homo Zapiens, the viewer becomes a remotely controlled television program. ${ }^{8}$

Each human being becomes a cell of an organism known by the ancients as the mammon, or simply Oranus (rotozhopa). The purpose of each cell is to allow money to pass into and out of it. In the process of its evolution, Oranus develops a primitive nervous system, the media. This nervous system transmits "wow impulses" that control the activity of the monadic cells: oral (inducing a cell to digest money), anal (inducing it to eliminate money), and displacing (inhibiting all psychological processes that might hinder an individual's identification with a cell of Oranus). After repeated exposure to television, the mind commences to produce these impulses without external stimulation. Each monad is once and for all trapped in a cycle of consumption-excretion, a Perpetuum Mobile of consumer culture. Commodities are no longer linked to specific functions but operate in a mechanism of insatiable social desire that supplants other kinds of desire, including sexual ones.

In (the spirit of) Che Guevara's argument, the transformation of Homo Sapiens into Homo Zapiens constitutes an unprecedented rupture. For the first time in history, the problem that previous repressive societies never resolved is effectively settled - the obliteration of man. The new categorical imperative is to consume and to eject money. A mocking combination of dialectical materialism, Buddhism, and twentieth-century bourgeois critique of consumerism, Che's treatise adds Kant to the picture as well. Che's meditations on

${ }^{7}$ Viktor Pelevin, Generation " $\Pi$ " (Moscow, 1999), 7. The translations borrow from Viktor Pelevin, Homo Zapiens, trans. Andrew Bromfield (New York, 2002), with modifications.

${ }^{8}$ Ibid., 104-7. The menacing role television plays in the novel recalls Orwell's two-way television screens that discharge propaganda and monitor behavior. However, methods of control are quite dissimilar. 
old-school dualism as engendered by the arbitrary division of the world into subject and object tap into Kant's reconsideration in The Critique of Pure Reason of the Cartesian dichotomy between the subject and object of knowledge. The new rupture parodically "outdoes" Kant's "Copernican revolution" by dispensing with the subject of knowledge altogether. Through absorption into the sinister new monetary collective, the subject disappears. Since Oranus's cells no longer possess any inner being, all they can do is to define themselves via the possession of products advertised on television. Genuine interiority is exchanged for an illusion of interiority, a so-called identity. Money is viewed as an entity that removes humanity from humans and creates a primitive, parasitical organism incapable of cognition or even self-awareness, something of a perverted subpersonal rather than suprapersonal deity.

Generation " $\Pi$ " falls in line with numerous European and American postmodern dystopias that, following Huxley, focus on the ennoblement of greed and covert varieties of control in contemporary society. Pynchon's Vineland, DeLillo's White Noise, Coupland's Generation X: Tales for an Accelerated Culture, and Palahniuk's Fight Club are some examples of such work. ${ }^{9}$ Likewise, Pelevin's exploration of the process through which Homo Sovieticus gets transformed into Homo Zapiens is heavily informed by Western intellectuals' criticism of the electronic age with its mass conformity and boundless possibilities for the manipulation of consciousness. ${ }^{10}$ The disappearance of the subject is a staple of postmodern thought present in Derrida, De Man, Foucault, and others; the carceral nature of modern techno-informational society has been analyzed by, among others, Adorno and Foucault; the channeling of sex for society's purposes by Foucault; the absorption of historicity and culture into kitsch and the content-free nature of capital by Jameson; and the self-perpetuating cycle of consumer desire by Baudrillard. ${ }^{11}$

Of even more relevance are Baudrillard's notion of the simulacra, the displacement of reality by semiotic systems with no relation to the real, and Marcuse's studies of advanced industrial society. ${ }^{12}$ Carrying Baudrillard's ideas about simulated politics to their limits, Pelevin describes a Russia where reality has all but disappeared. It turns out that the country's very government is virtual: the highest officials are digital dummies on television whose movements are scripted by copywriters. The default of 1998 is brought on by a copywriter who "erased" the entire virtual government. In a hilarious play on the expression "critical

${ }^{9}$ For a comparison of Pelevin's novel and Douglas Coupland's Generation X see Sally Dalton-Brown, "The Dialectics of Emptiness: Douglas Coupland's and Viktor Pelevin's Tales of Generation X and P," Forum for Modern Language Studies 42:3 (2006).

${ }^{10}$ Pelevin's reliance on Western theory is clear enough, although this does not necessitate a typological parallel of marked intertextuality in Generation " $\Pi$ ". The author's familiarity with poststructuralist and other modern theories is evident from his essays. See, for example, "The Macedonian Critique of French Thought," in his DPP $(N N) /$ The Dialectics of the Transitional Period from Nowhere to Nowhere (Moscow, 2004).

${ }^{11}$ See, for example, Jacques Derrida, Margins of Philosophy (Chicago, 1972); Paul De Man, The Resistance to Theory (Minneapolis,1986); Michel Foucault, Discipline and Punish: The Birth of the Prison (New York, 1979); idem, The History of Sexuality (New York, 1980); Theodore Adorno, Prisms (Cambridge, MA, 1981); Fredric Jameson, Postmodernism, or, The Cultural Logic of Late Capitalism (Durham, 1991); and Jean Baudrillard, The Consumer Society: Myths and Structures (London, 1998).

${ }^{12}$ The influence of Baudrillard has been noted by Mark Lipovetsky in "Goluboe salo pokoleniia, ili Dva mifa ob odnom krizise," Znamia, 1999, no. 11. For more on simulacra see Jean Baudrillard, Simulations (New York, 1983); and idem, The Gulf War Did Not Happen (Bloomington, 1996). 
days" from a 1990s Tampax advertisement, the financial crisis itself functions as an ad for Tampax. If Baudrillard still leaves room for a metaphorical reading of his provocative thesis about the Gulf War, with some provisional "reality" beyond the virtual warfare presented for the benefit of the populace, then Pelevin's politicians are literally disembodied.

Analogously, Pelevin carries to the limits Marcuse's linkage of politics with media and of the subject with his function in modern society. ${ }^{13}$ According to Marcuse, commerce and politics tend increasingly to merge. By no means does this suggest a weakening of political power but, rather, a novel power model under which control is being implemented through daily routine, with the media mediating between the masters and the populace. A sweeping redefinition of thought itself is taking place. To circumscribe the individual fully within the social norm, concepts are redefined in operational terms, including the concept of the subject, which is now identified with its function. In Pelevin, the media literally equals politics, and the subject equals the goods. Media moguls create simulacra of politicians, and the consumer answers the question "Who am I?" as "I am the one who possesses X, Y, Z."

Marcuse's theory of "repressive tolerance" contends that the prevailing practice of toleration in advanced industrial society is but a hypocritical mask to cover oppressive political realities: "It is the governed who tolerate the government, who in turn tolerates the opposition within the framework determined by constituted authorities. Tolerance to that which is radically evil now may appear good because it serves the cohesion of the whole on the road to affluence and more affluence." 14 Specifically, the toleration of the systematic brainwashing of the populace by publicity, and the tolerance toward deception in merchandising, constitute the essence of a system which fosters tolerance to perpetuate the struggle for existence. In Pelevin the market complacently absorbs art and pseudo-art alike, fostering "“destructive tolerance' (Baudelaire) of 'benevolent neutrality" toward culture"; and all kinds of opposition are subverted by the system and turned to its own benefit. $^{15}$

Relying on a substantial body of Western criticism of consumer society, Generation " $\Pi$ " displays some features that distinguish it from familiar European and American analyses of ubiquitous consumerism and all-powerful technological control. Importantly, Pelevin depicts not an established consumer society but Russia's traumatic entrance into the brave new world of commodities. Much of the force of his work derives from its dramatization of cultural rupture. By portraying the violent imposition of an alien order of life, Pelevin makes the grotesqueries of commodified society stand out all the more acutely. ${ }^{16}$

The novel's teasingly elegiac opening refers to the pre-fall innocence of Homo Sovieticus that for generation " $\Pi$ " coincides with the innocence of childhood: "Once upon a time in Russia there really lived a carefree youthful generation that smiled in joy at the

\footnotetext{
${ }^{13}$ See Herbert Marcuse, One-Dimensional Man: Studies in the Ideology of Advanced Industrial Society (Boston, 1968), esp. 84-120.

${ }^{14}$ Marcuse, "Repressive Tolerance," in A Critique of Pure Tolerance (Boston, 1965), 82-83.

${ }^{15}$ Ibid., 88 .

${ }^{16}$ Although some of the traits portrayed are specific to Russian realities of the 1990s, Pelevin's critique is aimed at consumer culture at large. The country's grotesque infantile capitalism merely serves as an exaggeration of established commodified existence.
} 
summer, the sea and the sun and chose Pepsi." 17 "Once upon a time" (kogda-to) gives Soviet life a distant-past, almost fairy-tale-like quality. "Really" (i pravda) further strengthens the mythological, hard-to-believe feel of the stance. Within the very first sentence, elegy dissipates through a quick move from a prolonged "lived" (zhilo) to onetime acts of "smiled" (ulybnulos') and "chose" (vybralo). The next sentence, "it's hard to figure out now why this happened," also conveys the feeling of the distant obscurity of the Soviet past, incommensurate with the short length of time that has actually elapsed since the fall of the USSR. ${ }^{18}$ The interweaving of Babylonian and Soviet mythologemes subsequently in the narrative will communicate, among other things, the same deceptive feeling of immense historical distance separating post-Soviet times from the Soviet epoch. ${ }^{19}$

Initially, Tatarsky displays an intensely estranged perception of the new way of life. In a twist on the narrative pattern from More's Utopia, he is a visitor from another place or time who encounters an amazing new realm, except that in this case the realm is utterly dreary. A locus of naive dreaming in the Soviet psyche, the distant forbidden world of commodities proves to be anything but a utopian fantasy. Significantly, the transformation of Russia into a consumer society is presented not merely as a displacement of one social system by another, even if the systems are antithetical, but as a radical ontological and epistemological break: "The very space into which their gaze had been directed ... began to curl back in on itself and disappear, until all that was left of it was a microscopic spot on the windshield of the mind. ... It was not possible to say that the world had changed in its essence because now it no longer had any essence. A frightening uncertainty reigned over everything." ${ }^{20}$ Tatarsky and his compatriots are lost in a murky antiland where "eternal" laws of space and time no longer apply. It is not that society is crumbling: reality itself is crumbling in Russia. The narrator reinforces the same uncomfortable feeling of ontological/ epistemological confusion when he describes the removal of Lenin's statues: "But he was only replaced by a gray frightening murk.... The newspapers claimed that the whole world had been in this frightening murk for ages, which is why it is so full of things and money, and the only reason people cannot understand this is their 'Soviet mentality."' 21 The peculiar term "gray frightening murk" (seraia strashnovatost') echoes the "frightening uncertainty" (strashnovataia neopredelennost') from the previous quotation. The material is replaced by amorphous abstractness, emphasizing the befuddling nature of the new reality. ${ }^{22}$ The work juxtaposes retreating Soviet mentality and the new mindset, not always in favor of the latter. Harshly critical of Soviet mythology in his earlier works, Pelevin reflects here on a depressing value void that opens up following the deconstruction of Socialist utopia. Elsewhere, and now in Russia, commodities serve to disguise metaphysical emptiness.

Lest one is tempted to read Generation " $\Pi$ " as a straightforward nostalgic project, one should note persistent parallels Pelevin is offering between the "loser" (the Soviet

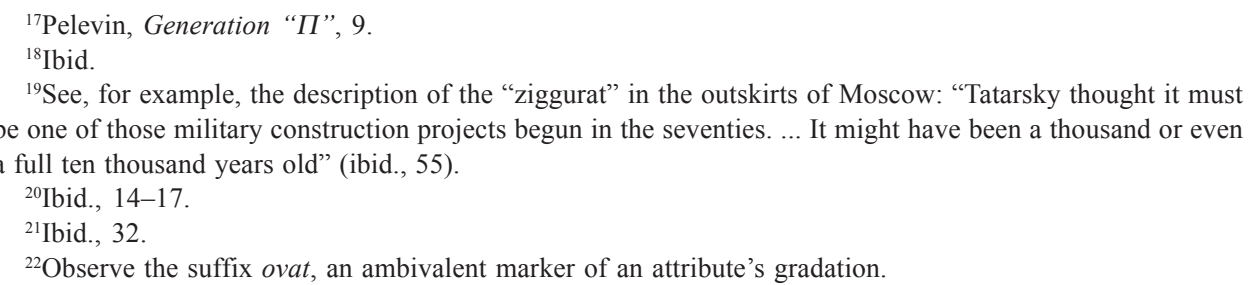


mythologeme) and the "winner" (the consumer mythologeme). The displacement of one pernicious ideological system by another, no less insidious but likely possessing more vitality, is formulated sardonically from the outset as the "historical victory of the red [Coca-Cola] over the red [communism]." ${ }^{23}$ Tatarsky and his fellow copywriters are the ideologues of the new dystopia, imposing the values of a market economy on the pliant populace just as their predecessors were imposing the values of communism. Tatarsky's places of work, advertising agencies in the former "Pravda" complex, and later in a large Stalinist-style building from the 1940s, underscore this notion. To further drive the point home, Pelevin describes a Stalinist poster in which the hammer, the sickle, and the star are replaced with Coca-Cola and Coke so neatly that one does not even notice the transformation. He also mentions that in Spanish the word for "advertising" is "propaganda."

According to the novel, however, there are crucial differences between the Soviet and the consumer mindset. By no means idealizing the Soviet past, Pelevin suggests that the mentality of Homo Sovieticus embraced eternity, while the mentality of Homo Zapiens dispenses with it:

Something also began happening to the very eternity to which Tatarsky had decided to devote his labors and his days. ... It turned out that eternity existed only as long as Tatarsky sincerely believed in it, and was nowhere to be found beyond the bounds of this belief. In order for him to believe sincerely in eternity, others had to share in this belief because a belief shared with no one is called schizophrenia. ... He also understood something else: the eternity he used to believe in could exist only on state subsidies, or else - which is the same thing - as something forbidden by the state. ${ }^{24}$

The meditations on the disappearance of eternity in Russia have been interpreted as the post-Soviet intelligentsia's loss of faith in the values of culture. ${ }^{25}$ A closer look at the passage will reveal important additional layers of meaning. As the former Soviet Union joined the family of "normal" market economies, Russian logos entered the era of worshipturned-recreation. The poet, once "more than a poet," in Evtushenko's aphorism, became an equivalent of oneself, and, frequently, less than that. ${ }^{26}$ In one of his sprightly paradoxes, Pelevin suggests that eternity was nurtured by, and in opposition to, the autocratic system. Indeed, peaks of culture often occur under tyrannical regimes. Russian logos, in particular, was tempered and pampered by an extended autocratic tradition, deriving much of its moral force from fighting the ignominy of the state. As the novel is to show, commodified society is more destructive to culture than authoritarianism.

That art is a substitute religion of modernity is a common enough notion, articulated by Nietzsche among others. ${ }^{27}$ Insofar as Russian logos was traditionally insistent on

${ }^{23}$ Ibid., 11.

${ }^{24}$ Ibid., $13-15$.

${ }^{25}$ Lyudmila Parts, "Degradation of the Word or the Adventures of an Intelligent in Viktor Pelevin's Generation ' $\Pi$ ', 'Canadian Slavonic Papers 46:3-4 (2004): 444. The article provides an insightful analysis of the theme of the intelligentsia in the novel.

${ }^{26}$ Evgenii Evtushenko, Stikhi (Moscow, 1999), 76.

${ }^{27} \mathrm{See}$, for example, Friedrich Nietzsche, Human, All-too-Human, trans. R. Hollingdale (Cambridge, England, 1996). 
endorsing itself in ethical and even religious terms, one is tempted to reinterpret the loss of faith in eternity as a loss of faith in culture, religion by proxy. The destruction of eternity in the novel, however, is not confined to the defeat of culture. Rather, the book portrays a total collapse of spirituality, including spiritual values traditionally unrelated to the Russian cultural sphere and involving the less educated part of the populace as well as the intelligentsia. To look at the same issue from a different angle, the very tightness of the link between culture and religion in the Russian context implies that the desacralization of culture described by Pelevin has overwhelming spiritual implications for the people's spirit at large.

Distant spiritual systems disappear along with the Soviet world. Thus, Tatarsky's Buddhist friend Gireev "seemed like the final fragment of some lost universe - not the Soviet one because it did not have any wandering Tibetan astrologers, but some other world that had existed in parallel with the Soviet one and even in contradiction to it but had perished together with it." ${ }^{28}$ Buddhism proves as alien to Brave New Russia as do more traditional spiritual values. In Pelevin's portrayal, metaphysical visions of the post-Soviet esoteric wave are commodified and thus degraded by consumer society. Picking up on contemporary fascination with the occult, Pelevin clashes mystical practices and consumerist realities of the era. The Ouija board used to communicate with Che is bought in the shop "Path toward Oneself," which sells all kinds of occult paraphernalia. No less importantly, the esoteric (Babylon) layer of the text with its Biblical connotations of greed and corruption is purposefully chosen, and played with, to coordinate with the earthly dystopia. In the novel's version of this mythology, ancient Babylonians equate supreme riches and power with supreme wisdom. To obtain them, one has to enter sexual union with Ishtar's golden idol, winning the "great lottery." This means answering the three riddles of Ishtar, the answers to which are hidden in the words of market songs. The striking equation of wisdom with power and riches, the "golden idol," the "great lottery," and "market songs" all reveal the myth's monetary obsessions. In his ascent to the upper echelons of power, Tatarsky accomplishes all of the above. As a result, allusions to post-Soviet esoteric metaphysics do not problematize but reinforce Pelevin's diagnosis of the collapse of spirituality.

It was suggested that Tatarsky views eternity in mythological terms..$^{29}$ Given Pelevin's intense subjectivism, the disappearance of faith in eternity means the disappearance of eternity itself. ${ }^{30}$ What matters is not whether eternity exists in the mind of people or "as such," for nothing exists "objectively" - as Pelevin persistently asserts in his oeuvre—but rather the spirit-nurturing or spirit-stifling nature of myth shared by the community of believers. In Pelevin, Soviet mentality supports metaphysical idealism, and the destruction of the former is attended by the destruction of a modest but spiritual worldview.

A distinction between the old Soviet and the new consumer consciousness is formulated by one of Tatarsky's employers, Dmitry Pugin:

\footnotetext{
${ }^{28}$ Pelevin, Generation " $\Pi$ ", 46. Also see the end of chapter one on the loss of eternity by the saleswoman Man'ka.

${ }^{29}$ Parts, "Degradation of the Word," 444.

${ }^{30}$ In Pelevin's work the mind creates reality. See, for example, "Vera Pavlovna's Ninth Dream," in his Vse rasskazy (Moscow, 2005); Omon Ra: Zhizn' nasekomykh (Moscow, 1999); and Chapaev and Emptiness (Moscow, 1996).
} 
In New York you realize especially clearly ... that you can spend your entire life in some foul-smelling little kitchen, staring out into the some shitty little yard and chewing on a lousy burger. ... Right, there are many more stinking kitchens and shitty yards over here. But here you will never realize that that's where you will spend all of your life. Until you spend it all, that is. And that, by the way, is one of the main features of the Soviet mentality. ${ }^{31}$

Both Homo Sovieticus and Homo Zapiens are victims of their respective societies. If the former harbors illusions about life, not necessarily in ideology-specific terms but in a more universal Romantic sense, the latter often has no illusions at all about his lot or the regime but is nevertheless caught in consumer dystopia as firmly as the naive Soviet man in his web of Maya. The signifiers of Socialist ideology point at transcendental meanings, however unattainable; the signifiers of consumer culture bear no meaning at all except one of expenditure. Pelevin's postmodern heroes realize the vacuity of their existence, yet they fully abide by the rules of the game. In the new society, technology brings vast possibilities of social control, and the success of society depends not so much on the power of ideological phantoms to dupe individual human beings as on the self-perpetuating power field of the entire structure in which humans/cells are functioning as they ought to, whether duped or not.

Besides staging the country's tumultuous transformation into a market economy, the novel forcefully combines Western theoretical models with a rich Russian heritage of antimaterialist thought. Dostoevsky, likely the most eloquent Russian spokesman against materialism, is the first one on the list. Tatarsky's last poem alludes to Svidrigailov's existential nausea:

What is eternity-it is a bath-house,

Eternity is a bath-house with spiders.

If Man'ka forgets it

What will happen to our Motherland and to us? $?^{32}$

An unlikely combination of Dostoevsky and the perestroika-era hit "What Is Autumn?" by the Russian rock band DDT, the poem blends Russian classical culture and late Soviet nonconformism in a general nostalgic thrust.

The premonition of Dostoevsky's underground man that, in a rationalized dystopia, science will discover a way of fully accounting for, and therefore fully controlling, human will, the idea that "man will have ceased to have a will of his own-he will have ceased even to exist," is realized to the letter according to Che Guevara's treatise. ${ }^{33}$ Unable to transcend personal interests, man becomes a conscious if soulless entity that can be easily manipulated through sensory stimuli. The more technically developed society becomes, the more the moral degradation of its populace stands out.

As the narrative unfolds, allusions to Dostoevsky multiply. Copywriter Morkovin revises Raskolnikov's "Was I a trembling creature or had I the right?" into "I am a trembling

\footnotetext{
${ }^{31}$ Pelevin, Generation " $\Pi$ ", 33-34.

${ }^{32}$ Ibid., 16. Fyodor Dostoevsky, Crime and Punishment (New York, 1989), 245.

${ }^{33}$ Dostoevsky, Notes from Underground (New York, 2001), 19.
} 
creature who has inalienable rights [to money]." ${ }^{" 34}$ Later Dostoevskian evocations include "an old man called Zosima who was horrified by intimations of material fire"; virtual dummies of politicians produced from "stiffs" and "semi-stiffs" (bobki i polu-bobki); the nuclear jet-powered cruiser "The Idiot"; and Tatarsky's desperate appeal to the spirit of the writer when assigned the task of advertising the Russian Idea. ${ }^{35}$ Each time Dostoevsky is amusingly rewritten to comment on new consumer realities. Raskolnikov's "right" to murder as proof of his supermanhood is transposed appropriately enough as the right to superlarge amounts of money while remaining a self-assured "louse." Father Zosima's antimaterialism is incorporated into the novel's chain of associations television-consumerism-Gehenna. The fantasy of talking corpses becomes the phantasmagoria of simulated politics. The universal "victory" of "goodness and beauty" advocated by the writer is represented by the Soviet warship now pawned off to the West. As the prophet of the Russian Idea, Dostoevsky is contacted via Ouija board, with most disappointing results. The board starts trembling and leaping into the air, as though pulled in different directions at once by several spirits, and all that is left on the paper are crooked scribbles. The last joke covers Dostoevsky's struggle with contradictory ideas, the renowned polyphony of his novels, his fury at being employed at such an ignominious task, and the bankruptcy of the Russian Idea under the new regime.

The novel's mythological and eschatological layers clearly evoke Dostoevsky's condemnation of materialism. Steeped in Babylonian mythology, the novel portrays the protagonist's career rise simultaneously as a mystical ascent along Ishtar's ziggurat. At the end, Tatarsky becomes the supreme creator of virtual reality and the husband of the golden goddess. In Winter Notes on Summer Impressions and The Idiot, for example, Dostoevsky employed Babylonian mythology to couch his critique of Western mechanical, utilitarian civilization. In the former work, Western materialist civilization, as embodied by London, is precisely "a Biblical picture, something about Babylon, some kind of a prophesy from Apocalypse taking place before your very eyes. You feel that you need a great deal of eternal spiritual resistance and negation in order not to succumb to impressions, not to bow before facts, and not to deify Baal." ${ }^{36}$ Like Dostoevsky, Pelevin underscores Babylon's apocalyptic connotations. Ancient Hittite mythology per se is coordinated in Generation " $\Pi$ " with Babylonian motifs in the Bible. Moscow is the new "whore of Babylon" from Revelations, destined for destruction due to its dismissal of all values beyond the material sphere.

For once, Russia's mythologized spiritual immunity to the idol of Baal is found wanting. The former devotees of the spirit swiftly succumb to market realities. Pelevin's dedication, "to the memory of the middle class," refers to the degraded version of the intelligentsia under the new conditions. ${ }^{37}$ As stated in the novel, "the middle class in Russia is formed directly from the intelligentsia, which ceased thinking nationally and turned to the question

\footnotetext{
${ }^{34}$ Pelevin, Generation “ $\Pi$ ”, 22; Dostoevsky, Crime and Punishment, 354.

${ }^{35}$ Pelevin, Generation “ $\Pi$ ”, 155, 207, 268, 181. Zosima, of course, refers to The Brothers Karamazov, and bobok to the story "Bobok."

${ }^{36}$ Dostoevsky, Winter Notes on Summer Impressions (Evanston, 1988), 42.

${ }^{37}$ Pelevin, Generation “ $\Pi$ ”, 5.
} 
of where it can get money. ${ }^{\prime 38}$ The default of 1998 depicted at the end of the book undermines the emerging post-Soviet middle class. Simultaneously, the epigraph designates the Soviet intelligentsia as the middle class, presenting an ironic anachronism that exposes the power of new consumer paradigms to impose themselves on the past, effectively erasing the past's own values.

As the novel demonstrates, all values, including the most prized ones of Russian national particularity, turn into market values under the new conditions. Indeed, it is precisely one's most cherished ideals, including the ideal of Russia's unique spiritual resistance to materialism, that sell particularly well. In Pelevin's sardonic observation, "that which is most sacred and exalted should be sold at the highest price possible because afterwards there will be nothing to sell. ${ }^{3} 39$ An ad for Smirnoff vodka, with a picture of Tiutchev in a chair standing on the ceiling, and the slogan "One cannot understand Russia with the mind, one can only believe in it," written in the original but transliterated into Latin characters, exemplifies advertising's perversion of the idea of Russian uniqueness. ${ }^{40}$ That the time of Russian culture is running out is suggested by an ad for Gap in which the outline of the gap between Anton Chekhov's legs becomes a gothic hourglass, with almost all the sand fallen through to the bottom, and the slogan "Russia was always notorious for the gap between culture and civilization. Now there is no more culture. No more civilization. The only thing that remains is the gap. The way they see you." ${ }^{\prime 41}$

In the logic of the marketplace, the Russian Idea becomes a monetary auxiliary because some kind of a national paradigm must accompany capital in order for this capital to position itself successfully on the international market. Since the prerevolutionary "Orthodoxy, Autocracy, and Nationality" and the Soviet "Victory of Communism" are both passé, the media must come up with a clear and simple brand essence with which to garnish monetary transactions. For Pelevin, no such native paradigm can be found. Since alternatives that can genuinely oppose global consumerism and popular culture no longer exist, simulacra concocted by the media proliferate. For the domestic market, the concept of nationhood defined against the shortcomings of "the other" can be one profitable strategy. An advertising concept for Russian Golden Iava cigarettes proposes the drawing of a bird's-eye view of New York, with a pack of Iava diving at the city like a nuclear warhead. The concept taps into the nostalgic imperial mentality that surfaced in the 1990s, gradually ousting a critical reevaluation of the Soviet past characteristic of the perestroika period. Phony Slavophilism, manipulating a now-fashionable glorification of prerevolutionary Russia, is another efficient solution. This means packaging Western goods in a pseudo-Slavic style, as in an ad for Sprite: "In the spring time forest I drank my birch Sprite." ${ }_{42}$ Whether injured imperial sensibilities or a clichéd, obtuse presentation of traditional Russianness are put on clearance, Pelevin captures a key trait of the new society. Commodified versions of worldviews both hollow them out, offering their cheaper, profit-driven adaptations, and conceal this

${ }^{38}$ Ibid., 255.

${ }^{39}$ Ibid., 30 .

${ }^{40}$ Ibid., 77. See also Fedor Tiutchev, "Umom Rossiiu ne poniat'," in his Stikhotvoreniia (Moscow, 1969), 127.

${ }^{41}$ Pelevin, Generation " $\Pi$ ”, 85.

${ }^{42}$ Ibid., 37. 
hollowed-out nature by transforming what should have been a full cognitive-emotional process into a reflex of acquisition.

The novel explores the intricate interweaving of the local and the global that takes place under globalization. Home-specific beliefs are presented in such a hackneyed way that the celebration of the local as such is already conditioned by the global. Exploration of difference degenerates into marketing of difference. All kinds of opposition are turned to the system's benefit. This is highlighted when, for instance, the hero listens to Che Guevara's denunciation of capitalist society, wearing the well-known T-shirt with the revolutionary's face on it and the slogan "Rage against the machine." Clearly, Che of the novel has little to do with the Cuban communist. He is a second-order phenomenon, a flourishing Western leftist brand. A postmodern political strategy is put forth: it is not necessary to apply brute force to suppress dissent, merely to optimize its market value. Che's subversive treatise itself inspires Tatarsky in his advertising concepts and helps him rise on the media ladder. The second Gap ad, with an Afghan veteran throwing a stone into a shop window while screaming, "It was heavier under Kandagar!" and two versions for Nike, one playing with a mass suicide of members of the occult group "Heaven's Gate," and the other involving American prisoners in Vietnam, are examples of multiple advertisements in the second half of the novel that effectively sell opposition. ${ }^{43}$

Pelevin's deconstruction of dissent is meant to be applied first and foremost to the text itself. As the novel points out, in a consumer dystopia "books and films will appear in which the dominant element of content will be a secret hymn of praise to Coca-Cola and an attack on Pepsi-Cola - or vice-versa," and "even the illusion of critical assessment of what takes place on the screen [in the book] is itself part of the induced psychological process." ${ }^{\prime 4}$ A member of Generation P(epsi), by the conclusion of the book Tatarsky revolutionizes Russia into a Coca-Cola country. To reinforce the idea, an ad for Sony television replays Tatarsky's drug-induced revelation about the media as the modern tofet or Gehenna: "Did you think there was a vacuum behind the absolutely flat Black Trinitron's screen? No! There's a flame blazing there that will warm your heart! The Sony Tofetissimo. It's a Sin." 45 "Tofetissimo" echoes "tofet," and "sin" is a bilingual pun on "dream" (son). Both fall into Che's critique of the media as a purveyor of avarice and illusions. This kind of advertisement is a new advertising technology aimed at circumventing and putting to use growing human distaste with market mechanisms.

Intensely self-referential (not in the traditional modernist sense of literaturnost' but including the commercial pragmatics of text production), the novel itself embodies Pelevin's pet idea that "nothing sells as well as a well-packaged and politically correct rebellion against a world that is ruled by political correctness and in which everything is packaged to be sold." "46 Biographic and stylistic parallels between Pelevin as writer and Tatarsky as copywriter help to reinforce the text's auto-referentiality. Like his author, Tatarsky studied engineering and enrolled at the Literary Institute. His advertising concepts are written in

\footnotetext{
${ }^{43}$ Ibid., 300, 126-29.

${ }^{44}$ Ibid., $116,112$.

${ }^{45}$ Ibid., 239.

${ }^{46}$ Ibid., 96.
} 
Pelevin's signature style, which mixes the widest possible range of cultural languages and liberally employs puns, paradoxes, and aphorisms. The novel suggests that, under the impact of commodity form on cultural production and reception, literature is linked to advertising.

The work dramatizes a new close relationship between art and commerce in a variety of ways. One is employing the idiom of copyright in the body of the text, right after the epigraph: "All trademarks mentioned in the text are the property of their respected owners. All rights are reserved. Names of goods and politicians do not indicate actual commercial products and refer only to projections of elements of the commercial-political informational field that have been forcibly induced as objects of the individual mind." ${ }^{47}$ Objects and politicians alike are merchandise, and so is art. To appeal to the widest target group, both "high cultural" and "pulp" editions of the novel were issued by the publishing house Vagrius in the year of the novel's release. The former has a reserved gray cover, customary for Vagrius, with the reproduction of Brueghel the Elder's renowned painting, The Tower of Babel. The cover of the mass-market edition shows Che Guevara in a beret with the Nike logo surrounded by Coca-Cola and Pepsi logos. The inside covers present a Che with a completely symmetrical face (another comment on the reproducibility of commercial images) and offer a slogan: "Time for rent, space for rent." The interjection "Wow-Vau!" on the back cover conditions the reader's response like a laugh track in sitcoms and simultaneously Russifies "wow" for domestic consumption. ${ }^{48}$ The letter " $\Pi$ " in standard quotation marks in the high cultural edition becomes,$\Pi$ ' in the mass market edition, referencing the obscene term pizdets (written with two commas, as the novel indicates), which stands for the apocalypse. The cover of another mass-market edition, issued in 2002, has a brick wall with three images of Che, one symmetrical in the middle and the left and the right ones as mirror images of each other, the title of the novel scribbled on the wall in graffiti style, and a new pseudo-copyright statement that parodically rewrites dystopian thought control: "All the thoughts that may enter the reader's mind are subject to author copyright. Their unsanctioned contemplation is forbidden." As far as global "positioning," Andrew Bromfield's translation has been released in the United Kingdom as Babylon and republished in the United States as Homo Zapiens, likely catering to the more "classical" and the more "modern" sensibilities on opposite sides of the Atlantic.

Just as diversely packaged editions of the novel target both the intelligentsia and the more unassuming members of the reading public, the novel's highly self-conscious marketing strategy included a section of the book published on the Internet before the book itself was released. ${ }^{49}$ The chapter entitled "Little Vovchik" was strategically chosen to advertise the novel. It alludes to Pelevin's highly successful preceding work, Chapaev and Emptiness, through a "Buddhist" explication of advertising and offers an entertaining preview of

${ }^{47}$ Ibid., 5.

${ }^{48}$ Lev Rubinshtein notes that "wow" "directly prescribes to us the expression of delight" in "Kogda zhe pridet nastoiashchii 'P'," available at http://pelevin.nov.ru/stati/o-rub/l.html (last accessed March 17, 2003).

${ }^{49}$ This excerpt, no longer accessible, was at http://www.kvest.com/arc/pelevin1.html. 
the new book's preoccupations with commerce, advertising lingo, the media, and the Russian Idea. ${ }^{50}$

Generation " $\Pi$ " posits itself, self-reflexively and sardonically, as both a condemnation of Brave New Russia and as its successful offspring. A dystopia in the traditional sense, it is also, in a more unorthodox way, a "dystopian product" that dramatizes its awareness of that fact. Does the novel's operative paradox short-circuit Pelevin's dystopian critique? ${ }^{51}$ In other words, given that Pelevin simultaneously claims that consumer culture commodifies and thus neutralizes attempts at social critique, and foregrounds his text as a product of this consumer culture, does the novel undermine its critique of consumerism? According to the logic of the book itself, yes. In Pelevin's terms, a mere awareness of one's commodified nature, displayed by the text's metacommentary, does not constitute a transcendence of commodification. Like the Sony ad, the novel is allegedly

a new advertising technology reflecting the reaction of market mechanisms to the increasing human revulsion at market mechanisms. To cut it short, the viewer [reader] is gradually to develop the idea that somewhere in the world ... there is a final oasis of freedom unconstrained by the thought of money. ... It's profoundly anti-market in form, so it promises to be highly market-effective in content. ${ }^{52}$

The fact that Pelevin undermines his own critique in the very process of expressing it is the fundamental paradox of his procedure. The bifurcated nature of the text (through the selfundermining ironical framing of consumerism critique) clearly ministers to postmodern ironic sensibilities. ${ }^{53}$ Semantic undecidability of the paradox suits the revisionist temper of the times. Yet the exposure of the operative paradox (the text as simultaneously a commodity and a critique of commodities) does not exhaust all the novel's workings. Appreciating the paradox does not necessarily lead the reader to dismiss Pelevin's social critique. Pelevin's suggestion that the book's dominant element is secret praise of Coca-Cola or Pepsi is a playful provocation rather than a convincing restatement of the novel's contents. It is also no accident that the work, exhaustively laying out its twists and turns, does not explicate how "the illusion of critical assessment of what takes place on the screen [in the book]" occurs. Is this "illusion" another red herring, prompting the reader to brush aside Generation " $\Pi$ " with a wry smile? Is the reader's critical assessment of Pelevin's dystopian society truly illusory?

\footnotetext{
${ }^{50}$ The lama who arrives in Moscow to lecture on advertising is Urgan Dzhambon Tulku the Seventh, the "author" of the preface to Chapaev and Emptiness, 9.

${ }^{51}$ The formal absurdity exposed here resembles Epimenides' or the Liar's Paradox. With respect to Pelevin's subject matter, the paradox may be rewritten as: 1) All social critique is neutralized by consumer society; 2) If all social critique is neutralized by consumer society, Pelevin's critique is neutralized as well; and 3) Is Pelevin's social critique effective? This type of logical inconsistency cannot be resolved unless one employs the restriction that one cannot apply truth locutions to sentences themselves containing truth locutions.

${ }^{52}$ Pelevin, Generation “ $\Pi ”, 239$.

${ }^{53}$ The title itself offers plenty of space for the play of the signifier. Most obviously, "П" stands for Pepsi and pizdets. It has also been interpreted as п (Mikhail Sverdlov, “Tekhnologiia pisatel'skoi vlasti," Voprosy literatury, 2003, no. 4:18), and emptiness (pustota) (Dalton-Brown, "The Dialectics of Emptiness, 247). Additional possibilities include Pelevin, postmodernism, post-Soviet, after (posle), consumption (potreblenie), memory (pamiat'), lost (poteriannoe), and so on.
} 
The contradictions and paradoxes of the novel cannot be fully resolved. ${ }^{54}$ It is perhaps up to the reader to decide to what extent Pelevin invests in his indictment of consumer realities, and whether his all-pervasive irony is largely a tribute to fashion or something more substantial. Likewise, it is up to the reader to decide whether the novel offers a compelling critique of consumer society, problematized or not, and whether the selfsubversive elements of his work are contained in dystopian subversion or vice versa.

The ironization of social critique is one prominent point of departure from classical twentieth-century dystopias that has come up in the course of my analysis. How else does Generation " $\Pi$ " refurbish dystopian conventions?

The position of art in utopia/dystopia is one of the genre's recurring themes from Plato's Republic onward. Shakespeare figures in both Brave New World and 1984, just as Pushkin does in We. The removal of the faculty of imagination signifies spiritual death for Zamyatin's protagonist. Classical dystopias present genuine art as an aesthetic and ethical antidote to the snares of ideology as well as the products of ersatz culture. Like Zamyatin, Huxley, and Orwell, Pelevin contemplates the effect of social and technological development on artistic creativity. In contrast to them, he portrays art's total subversion by kitsch. The humiliation of the artist under the new conditions is satirically enacted through the appearance in the novel of the hamster Rostropovich (referencing, in a double lunge, a renowned cello player and Soviet-period dissident) belonging to the media mogul Azadovsky, to whom Azadovsky awards medals of honor when in a good mood. Tatarsky's early advertising concepts recycle famous literary quotations as "a relic white noise of the Soviet psyche." "White noise," a designation of meaningless auditory stimuli, also used as the title of DeLillo's dystopia, suggests a loss of connection to predystopian art. The mounting tawdriness of the tasks to which art is put erodes its ability to function as a refuge from spiritual degradation. Simultaneously, the overselling of culture makes it no longer viable as a sphere of commerce. ${ }^{56}$ Later, advertisements replace classical allusions with references to New Russians, mafia, or pop culture. Art is thus first co-opted into the system and then dispensed with altogether. Reigning ersatz culture is merely another projection of Oranus, and a black money bag is the main focus of the viewer's/reader's attention.

Eroticism functions as another subversive element in classical dystopia. Zamyatin's D-503 and Orwell's Winston are propelled down the path of rebellion by their relations with I-330 and Julia, respectively; Huxley's John the Savage is revolted by his realization of Lenina's emotional sterility. In Pelevin, sexuality is not suppressed but channeled in ways beneficial to the system. ${ }^{57}$ Sex is valued as symbolic of the vital energy of youth that

\footnotetext{
${ }^{54}$ According to Linda Hutcheon, postmodern paradoxes "both reveal and question prevailing norms, and they can do so because they incarnate both processes. They teach that, for example, representation cannot be avoided, but it can be studied to show how it legitimates certain kinds of knowledge and, therefore, certain kinds of power." See Hutcheon, A Poetics of Postmodernism: History, Theory, Fiction (New York, 1988), 230.

${ }^{55}$ Pelevin, Generation " $\Pi$ ", 62. See, for instance, "World Pantene-pro V! God bless!" a tawdry twist on "World conflagration in blood, God bless," from Alexander Blok's "The Twelve" (ibid.; Aleksandr Blok, Sobranie sochinenii v vos'mi tomakh, ed. V. N. Orlov et al. [Moscow, 1960-63], 4:176).

${ }^{56}$ Observing a poster for a clothes boutique recycling Romantic clichés, Tatarsky comments that "the human mind had sold this romanticism to itself far too many times to be able to do any more business on the last remaining non-commercial images" (Pelevin, Generation " $\Pi$ ", 69).

${ }^{57}$ The channeling of sexuality also evokes Andrei Platonov's "Antiseksus" with its theme of ersatz-love. See Mikhail Ryklin, Terrologiki II (Tartu-Moscow, 1992), 215-18.
} 
can be converted into money rather than vice versa. Che Guevara's description of oral, anal, and displaced wow impulses jokingly reinterprets the Freudian psyche-sexual model as the monetary model. Tatarsky's only "erotic" encounter is with a thousand-dollar prostitute indistinguishable in darkness from Claudia Schiffer. At the end of the novel, the hero unites with Ishtar's golden idol or, on an abstract level, the idea of money. Like art, eroticism is translated into pecuniary lust.

As Tatarsky works his way up the media system, he struggles to comprehend what holds this system together. Following Dostoevsky's Grand Inquisitor, Zamyatin's Benefactor and Huxley's World Controller explicate their benevolent rule over the selfish and infantile populace to the novels' rebellious protagonists. Orwell's O'Brien, likewise, explains to Winston the rule of Big Brother and the inner party, although in this case any pretense of benevolent parental care is dropped. Orwell's rulers exercise power for sheer power's sake. In Pelevin, no Grand Inquisitor reveals himself. ${ }^{58}$ Tatarsky's discovery that the media creates virtual reality does not explain the system's workings. The oligarchs determine Russian national policy and inform the media of the latest trends, but, in a circular (il)logic, these very same oligarchs are virtual dummies created by the media. When Tatarsky asks what's holding the whole structure together, he is forbidden to ever contemplate the issue. Exasperated by the whole procedure, he wonders, "What bad bastard could have written this scenario? And who's the viewer who sits and stuffs his face while he watches this screen? And most important of all, could it all really only be happening so that some fat heavenly hulk can rake in something like money from something like advertising?"59 The passage blends commercial, metaliterary, and metaphysical rhetoric. In Tatarsky's eyes, the noumenal is a revolting "fat heavenly hulk" (zhirnaia nadmirnaia tushka) that authors people's lives, amuses itself by the spectacle, and collects its profits. The mercenary is a model of both authorship and ontology: the evil demiurge and the author mirror the copywriter.

Still later, he finds out that media moguls belong to a secret neo-Babylonian society with the purpose of defending the world against the apocalypse to be brought on by Ishtar's nemesis, the five-legged dog Pizdets. As Ishtar's new earthly consort, Tatarsky inquires again who rules over the world. The reply, as before, is not to pry into the issue if he wants to stay a "living god" for a comfortably extended period of time. In the words of the jingle that accompanies Tatarsky on his path to the top of the power structure, "this game has no name." Its purpose and the will of its players alike remain shrouded in mystery. Conspiracy theories of which postmodernism is enamored are dismissed by the novel. One of Pelevin's recurring symbols, an eye in a triangle from the one-dollar bill, parodically references a Masonic and an American "anti-Russian" conspiracy and rejects it immediately, pointing out that the eye sees nothing. Ultimately, the system is self-perpetuating, with copywriters pawning commodities off on people, and people pawning them off on each other, and back on the copywriters. Even the highest echelons of power live in the grip of consumerist simulacra and are unable to break through.

\footnotetext{
${ }^{58}$ Rodnianskaia notices the absence of a single ruling hand in the novel ("Etot mir priduman ne nami").

${ }^{59}$ Pelevin, Generation “ $\Pi$ ”, 223.
} 
The failure to understand the system is matched by the failure to resist it. In the classical dystopian scheme, the protagonist, a highly sympathetic human being, rebels in a gallant but hopeless attempt to assert the value of freedom and is destroyed by the brutal machinery of the state. By contrast, Tatarsky is swiftly assimilated by the powers that be. As Edith Clowes justly notes in her work on Soviet meta-utopias of the 1950s through the 1980s, "the best human being ... comes to understand the meshing of social laws and ideals in his life and chooses to say no, not to be driven by the rat race for power and influence, and to live according to his conscience." ${ }^{60}$ In his turn, Krishan Kumar suggests that a source of hope in dystopia may be found in a relatively free-thinking and independent upper stratum that society requires in order to handle the challenges it faces. ${ }^{61}$ In the cynical world of Generation " $\Pi$ ", no human being exists who is ready to apply his understanding of ideology against this ideology, and the members of the upper stratum are especially intent on preserving the status quo. Not only is Tatarsky co-opted by the establishment, but he himself attains a commanding position in it. As he becomes more closely acquainted with the power structures, he applies his familiarity with them toward his personal ascent. The hero views his work unsentimentally as a kind of prostitution, discerns the spurious nature of the new way of life, yet applies all his energies toward gaining a better position in the power race. No correlation between understanding and moral behavior obtains here.

Pelevin dismisses the "innocent victim" status of the protagonist and suggests that all the population of Russia is at fault for the chaos into which the country has fallen. In another paradox, "the anti-Russian conspiracy exists without any doubt. The problem, however, is that all the adult population of Russia takes part in it." ${ }^{.62}$ Members of generation " $\Pi$," a young, active part of the populace, are the first to blame. In Tatarsky's realization, they, having fallen into unbridled greed, are the eschatological Pizdets who is advancing on the world. ${ }^{63}$ This idea is developed on multiple levels. One is through Al-Ghazavi's poem, "The Parliament of Birds," about thirty birds who flew off in search of the bird called Semurg, only to learn that the word "Semurg" means "thirty birds." In mythological terms, as Ishtar's consort, Tatarsky dreams up this world, and the goddess of money herself obtains her life through this dreaming. Demonic motifs, jokingly presented but persistent, attend to the same theme. The "gray frightening murk" mentioned before references the gray, dusty realm of the demonic. Upon their first encounter, Morkovin introduces Tatarsky to advertising business with the phrase, "Let's go to the devil." "64 The metaphor is realized in the course of the book. During his first assignment as copywriter, Tatarsky receives a message on his pager: "Welcome to Route 666." ${ }^{65}$ Oranus and the god Enkidu, holding people threaded on his strings, both resemble huge spiders, developing Dostoevsky's

\footnotetext{
${ }^{60}$ Edith Clowes, Russian Experimental Fiction: Resisting Ideology after Utopia (Princeton, 1993), 24. The work discusses meta-utopias - narratives that critically examine diverse ideologies. The term would apply to Generation " $\Pi$ " as well.

${ }^{61}$ Kumar, Utopia and Anti-Utopia in Modern Times, 285.

${ }^{62}$ Pelevin, Generation “ $\Pi$ ”, 11.

${ }^{63}$ Gregory Freidin observes the significance of the last name Tatarsky (the Tartar yoke) in "Dzheneraishen 'P' (Generation 'P')," Foreign Policy, no. 118 (Spring, 2000): 166.

${ }^{64}$ Pelevin, Generation " $\Pi$ ”, 20.

${ }^{65}$ Ibid., 26.
} 
demonic theme of entrapment in universal evil. The name of Tatarsky's predecessor is Legion Azadovsky, and his manipulations with real estate in Moscow are strongly reminiscent of Bulgakov's The Master and Margarita. Tatarsky's "ascent" on the ziggurat culminates in his descent into "hell" by the Ostankino television tower to be anointed as a living evil deity. Generation " $\Pi$ " as " $\Pi$ " suggests mediocrity: its value cannot be captured exactly, but its specificities outside the sphere of its description are becoming more and more infinitesimal. A pedestrian member of a "pedestrian" generation, Tatarsky turns into the "petty demon" presiding over Russia's witch Sabbath.

Tatarsky's initiation into the secret cult at Zero Hour in the Golden Room suggests the onset of a new realm outside of time and history, a postapocalyptic timelessness. Permeated with eschatological symbolism, Generation " $\Pi$ " captures the mood of fear and disorientation that attended the breakup of the country and the first years under the new regime. The default of 1998 and the hysteria on the eve of the new millennium add to the picture. In the novel's comic eschatological terms, the Apocalypse is renamed the "Acapulypse," from Acapulco, the popular vacation resort. The destruction of the world is consumerism run amok. "Time for rent, space for rent" (vremia sdaetsia, prostranstvo sdaetsia), punning on the double meaning of sdaetsia as "for rent" and "gives up," likewise dramatizes the eschatological annihilation of time and space as a commercial venture. The struggle against history is complete.

Insofar as the depicted existence is unacceptable, a search for a different path is bound to present itself to the dystopian writer. Archetypal modernist dystopias suggest that a healthy alternative to the sterility of the state lies with the lowly "wild" masses outside the official sphere, who, untouched by totalitarian conditioning, are able to preserve indispensable human qualities of free will and love. Zamyatin's mephies, Huxley's inhabitants of the savage reservation, and Orwell's proles proffer a return to nature not as a literal reversion to savagery but as a metaphor for reawakening to the fullness of life, a regained ability to love, hate, and suffer again. In the words of Huxley's John the Savage, one needs "God, poetry, real danger, freedom, goodness, sin," and, in a Dostoevskian way, "the right to be unhappy." social scenario but fails to imagine venues of escape from dystopia, enacting a parodic apocalypse instead.

In the manner of Sots-art, Pelevin combines incompatible ideologies to comment on the misleading nature of all kinds of mythologemes. The ancient tyrannical divinity Enkidu resembles Cardinal Richelieu (Catholicism) and Vladimir Lenin (Socialism), just as CocaCola and Coke seamlessly replace the Soviet hammer and sickle on a Stalinist poster. The novel's alternative social scenarios are promptly discarded. A counterutopian "return to the roots" is rejected through a parody of contemporary Slavophilism, degraded into a virtual pseudo-Slavic commodity wrap-up. Pelevin's mockery of the leftist scenario is equally scathing. The liberal values of the 1960s, both in the USSR and in the West, are shown to be naively idealistic. Tatarsky's first name, Vavilen - a combination of Vasilii Aksenov and Vladimir Lenin given to him by his father-is as inept stylistically as it is misguided ideologically:

${ }^{66}$ Aldous Huxley, Brave New World (New York, 1932), 288. 
Tatarsky's father, it seems, found it easy to imagine a faithful disciple of Lenin gratefully learning over Aksenov's liberated page that Marxism originally stood for free love, or a jazz-crazy aesthete suddenly convinced by a particularly protracted saxophone riff that communism will win. But it was not only Tatarsky's father who was like that. The entire generation of the fifties and sixties was the same. ${ }^{67}$

Given knowledge of the subsequent history, an attempt to reconcile communist ideals and liberal values of the 1960s is bound for failure. What links Soviet shestidesiatniki and Western hippies is their infantile idealism, a naive belief that a sex-, jazz-, and marijuanainspired rebellion can offer a serious challenge to the system. In the eyes of generation " $\Pi "$, which has aged and hardened prematurely under duress, this is nothing but a mock rebellion, an overflowing of youthful vitality seeking its outlet. In an attention-gripping phrase, the fathers "ejaculated (konchili) the first Sputnik - that four-tailed spermatozoon of the future that never arrived - into the black emptiness of space." ${ }^{68}$ The double entendre of konchili, as "finished" and as "ejaculated," dramatizes the ironic bond between sexual and revolutionary drives as well as offers a dramatic closure on the idealism-of-space promise (a key staple of the Soviet myth, of the Thaw, and of Soviet utopia at large). The launch of the Sputnik is presented as the body politic's last vital deed. It goes wasted, followed by a descent into impotence. The demonic generation " $\Pi$ " are the children of these idealistic shestidesiatniki, recalling Pavel and Stepan Verkhovensky and their milieu in The Devils.

By the time generation " $\Pi$ " matures, the leftist scenario has become another brand in the world of brands. As pointed out, the novel ironizes not only consumer society but also the leftist critique of society as exemplified by Che Guevara's mock-scholarly treatise. In an additional joke, Che's spirit informs Tatarsky that the study of television is prohibited in every country except Bhutan, where television is forbidden. Since this theory is invented by one of Tatarsky's colleagues in the media, Che's critique is short-circuited again.

The dehumanizing effect of the new society is complete - man has been obliterated. If classical dystopias present cautionary tales, positioning their societies in the future and/ or in an imaginary locale (with Orwell placing it closest, thirty-five years from the time of publication), Pelevin's narrative, set in the 1990s, is the book's recent past. The unsettling notion that the novel does not lay out an "if this goes on" scenario but describes existing conditions is further reinforced by the inconspicuousness of its fantastic elements. The few "implausible" details, such as virtual politics, are seamlessly blended into post-perestroika realia and depicted with a journalistic topicality and precision of detail. Generation " $\Pi$ " is a realized dystopia.

The novel's mythological layer, importantly, buttresses the assertion of social and spiritual deadlock. Critics have suggested that post-Soviet narratives foreground epistemological hesitation, oscillating between alternate realities. As Alexander Genis aptly formulates it, "post-Soviet authors have come to see the world around them in terms of a sequence of artificial constructs, in which man is forever doomed to search for a 'pure,'

${ }^{67}$ Pelevin, Generation “ $\Pi$ ”, 12.

${ }^{68} \mathrm{Ibid}$. The deconstruction of space utopia is, of course, the focus of Omon Ra. 
'archetypal' reality. All these parallel worlds are not 'true,' without being 'false' either, at least while someone still believes in them." ${ }^{\circ 9}$ Given that Pelevin, true to the spirit of postmodernism, questions "authenticity" per se and overthrows conventional hierarchies, his works suggest not an indifferent array of alternate realities but an assemblage of parallel worlds, some of which are more conducive to the life of the spirit than others. The works are structured around the protagonist's struggle to escape the bounds of illusory simulated existence into genuine (self)-awareness. The attempt proves successful in his early work as, for example, in the case of Petr Pustota's breakthrough into Buddhist "Inner Mongolia" in Chapaev and Emptiness. Generation " $\Pi$ " also juxtaposes the phenomenal to the noumenal, but the noumenal is corrupted, a mere mirror image of the mundane, as in the case of the "fat heavenly hulk."

Commodified dystopia, Che Guevara's treatise, and Babylonian mythology are perfectly coordinated in the novel. In the protagonist's psychedelic hallucinations, the vision of the ancient Babylonian deity Enkidu replicates Che Guevara's image of Oranus. Like Oranus, Enkidu holds golden strings on which men are threaded, entering at the mouth and exiting from the anus. He is a fisherman who must gather all the people on his spindles of golden thread. When the task is complete, life on earth will cease. The same deity as the Biblical/ Dostoevskian Baal presides over tofet or Gehenna, where people are burned. In earthly terms, tofet/Gehenna is the modern media burning people in the fires of pecuniary desire. Inspired by his visions, Tatarsky begins his rise to the top. "Sacral" knowledge leads to worldly success. The myth, thus, does not permit a transcendence of the earthly but, on the contrary, constitutes a perfect embodiment of the society's monetary preoccupations. The dystopia's new religion is-literally - money.

While still searching for an authentic reality, Tatarsky comes up with a notion that, "in itself, a wall on which a panoramic view of a non-existent world is drawn does not change. But for a great deal of money you can buy a view from the window with a crudely painted ocean, an azure bay and a calm evening. ... Then perhaps the wall is drawn too? But drawn by whom and on what?"70 In terms reminiscent of Plato's "The Cave," he views commodities as systems of false symbols that serve to disguise man's metaphysical imprisonment. His insight is that consumer mythologemes are simulacra of the second order, hiding the primary simulacra-the illusion of the wall. Such an understanding may potentially lead to an escape from virtual reality. Instead, by the conclusion of the book Pelevin's protagonist becomes the ruler of Russia's virtual reality, and virtual reality himself - the hero of multiple advertising clips. The latest hopelessly bewildered Benefactor makes a meaningless swap of Pepsi for Coca-Cola, asks to take care of Rostropovich in a sardonic tribute to the fallen idols of culture, and exits the book in a highly pastoral Tuborg commercial, in thirty all too reproducible copies.

Instead of being a terrifying narrative of triumphant totalitarianism, Generation " $\Pi$ " emphasizes the farcical aspects of Brave New Russia. The novel offers its dystopian critique

\footnotetext{
${ }^{69}$ Alexander Genis, "Borders and Metamorphoses: Viktor Pelevin in the Context of Post-Soviet Literature," in Twentieth-Century Russian Literature: Selected Papers from the Fifth World Congress of Central and East European Studies, Warsaw, 1995, ed. Karen L. Ryan and Barry P. Scherr (New York, 2000), 297.

${ }^{70}$ Pelevin, Generation " $\Pi$ ”, 73.
} 
with a postmodern self-deprecating smile. The allegiance to studied detachment and literary games, however, cannot hide its quintessentially grim attitude to social processes. The methods of a Huxlean techno-consumer dystopia can be both more dangerous to the psyche and more politically insidious than the straightforward brutality of a traditional dictatorship. Portraying a self-perpetuating realized dystopia that subverts the saving qualities of art or erotic passion, implicates all the populace in the social impasse, fails to imagine ways of escaping from the deadlock, and even develops its own monetary metaphysics, Generation " $\Pi$ " is a most hilarious product of hopelessness. 